\title{
THE MILKMAN RINGS TWICE: \\ HAS PAUL V. UNITED STATES GIVEN FEDERAL PROCUREMENT REGULATIONS THE FORCE OF STATUTORY LAW?
}

\author{
JOHN R. DONNELIY*
}

Mr. Justice Douglas, speaking for the majority in Paul v. United States, ${ }^{1}$ stated in 1963 :

The earlier Regulation further stated that federal procurement officers should not require suppliers to comply with state price-fixing laws before it was judicially determined whether the latter were applicable to government contracts, ${ }^{2}$ a provision which the Court said manifested a federal "hands off" policy respecting minimum price laws of the States.

The present Regulation makes no such allowances, contains no such qualifications and provides for no such exception. Its unqualified command is that purchases for the Armed Services be made on a competitive basis; and it has, of course, the force of law. . . .

Justice Douglas has not changed his opinion since twenty years ago, when he wrote for the minority in Penn Dairies v. Milk Control Commission:4

A regulation which interprets "impracticable" so as not to preclude competitive bidding because of state price-fixing stays well within the scope of the rule-making power. These War Department regulations accordingly "have the force of law. . ." Their application in this case therefore has no less force and effect than if it was specifically directed by Congress....

What has changed in the intervening twenty years (apart from the decision of the Supreme Court) has not been the federal procurement policy as expressed by congressional statute, for even Justice Douglas admits the Armed Services Procurement Act of $1947^{5}$ simply revised and restated the time tested policy of competitive bidding, but the administrative regulations of one of the multitudinous federal agencies which engage in federal procurement. Does this changed regulation have the full force of statutory law? Can one federal agency by changing its regulations change the federal law? Suppose one federal agency-National Aeronautics and Space Administration (NASA), for example-which uses the Department of Defense

*A.B. I940, Duke University; IL.B. I947, Columbia University. Major, USAF, Chief Counsel's Office, George C. Marshall Space Flight Center, National Aeronautics and Space Administration, Huntsville, Ala. Formerly Staff Judge Advocate, Space Systems Division, Air Force Systems Command.

The views expressed herein are the author's and do not necessarily reflect the official views of any government agency.

37 I.S. 245 (I963).

2Id. at 254 (citing Penn Dairies, Inc. Milk Control Comm'n, 318 U.S. 26r, 276, 278 (x943)).

${ }^{3} I d$. at 255 (citing Public Utilities Comm'n of California v. United States, 355 U.S. 534, 542-43 (1958). (Emphasis added.)

318 U.S. $26 \mathrm{r}, 284$.

- 62 Stat. 2 r (r948), as amended, 70 Stat. $x_{30}$ (r958), ro U.S.C.A. \$\$ 230r-r4 (I962). 
(DOD) promulgated Armed Services Procurement Regulation (ASPR) under certain conditions and writes its own regulations under others, adopts conflicting regulations, which one is the supreme law of the land? And does saying that these regulations apply as though specifically directed by Congress mean that the ASPR, with all its standard clauses, has become in effect a basic agreement for all government contractors, regardless of contractual agreement?

\section{I}

Court of Ciatms Interpretation of Paul v. United StatesRegulations Applied Like Statutes

The Court of Claims, citing Paul v. United States, has gone to the extent of reading into a government Capehart Housing Act contract a standard-form military article providing for termination for the convenience of the government even though the contract did not include it, and even though the court admitted that the Armed Services Procurement Act did not cover the subject. Judge Davis stated for the court in G. L. Christian \& Associates v. United States, that ". . . a grant of wide and general authority to contract and procure will extend to all reasonable phases and methods"; and he also cited Priebe \& Sons v. United States for the proposition that "The power to purchase on appropriate terms and conditions is, of course, inferred from every power to purchase."7 This language, too, is the language of $\mathrm{Mr}$. Justice Douglas; but its use in the case appears strangely out of context, for in Priebe the Supreme Court struck down an attempt on the part of procurement officials of one federal agency to provide for liquidated damages which, under the circumstances involved, were held to amount to penalties: ${ }^{8}$

We are pointed, however, to no provision by which the Congress authorized the imposition of penalties as sanctions to that [Lend-Lease] program; nor do we find any. We cannot infer such a power. The power to purchase on appropriate terms and conditions is, of course, inferred from every power to purchase. But if that is the source of congressional authority to impose penalties, then any procurement officer, in war or in peace, could impose them. That is contrary to all our decisions on this question which involve government contracts.

The Court of Claims, however, is of the opinion that it may infer power in the Department of Defense to promulgate termination conditions from its grant of broad and general authority to contract. And because the Department has incorporated such conditions into a regulation which has the force of law, they may be read into a government procurement contract as if they were the words of a statute. But would the decision have been different in Priebe, if prior to writing the contract, the Lend-Lease Agency had adopted a regulation providing for penalties under the label "liquidated damages"?

- 320 F.2d 345, 348 (1963), cert. denied, 375 U.S. 954 (1963), rehearing denied, 376 U.S. 929 (1964).

${ }^{7}$ Id. at 348 .

${ }^{8}$ Priebe \& Sons v. United States, 332 U.S. 407, 4I3 (1947). 


\section{Douglas and the Supreme Court Opposition}

No one will argue with Mr. Justice Stewart's pronouncement for the minority in Paul v. United States: ${ }^{\ominus}$

I do not doubt that Congress in the exercise of its war power could by virtue of the supremacy clause provide that an otherwise valid state law affecting the price of milk shall not apply to milk purchased with federal funds for use at these military installations.

He then goes on to cite the majority in Penn Dairies: $:^{10}$ "An unexpressed purpose of Congress to set aside statutes of the states regulating their internal affairs is not lightly to be inferred and ought not to be implied where the legislative command, read in the light of history, remains ambiguous." Here the argument begins, on the part of Justice Douglas. Yet the gist of the thought sounds peculiarly like that of Douglas in Priebe. But Justice Douglas, although he discusses it in two paragraphs, does not rely on a specific statutory change by Congress, nor a clear legislative history; and he is not concerned with the problem of a state law imposing direct restraints upon a vital federal function, as in the California Commission case. ${ }^{11}$ How then did he find a change in federal policy? By the change in the ASPR, which "has, of ccurse, the force of law." Justice Stewart points this out when he says: "While the Court's opinion discusses this legislative history, I read the opinion as resting primarily on the Court's reading of certain executive regulations issued under the authority of the procurement law."12

Chief Justice Stone, in Penn Dairies, made two observations about Army regulations (which subsequently became War Department regulations) on state pricefixing laws $:^{13}$

The statutes authorizing the Secretary of War "to prescribe rules and regulations to be observed in the preparation and submission and opening of bids for contracts under the War Department," . . . give no hint of any delegation to the Secretary or his subordinates to do what Congress failed to do-restrict the application of local regulations, otherwise applicable to government contractors, which increase price. And the regulation itself is at most a direction to contracting officers not to assume by their specifications for bids any responsibility for requiring compliance with local price regulations before it is judicially determined whether such regulations are applicable to government contracts.

\section{III}

\section{The Supreare Court's Twenty Year Switch}

Justice Douglas does not, however, feel it necessary to overrule Penn Dairies; he distinguishes it on the grounds of changed conditions. He says that Congress, by

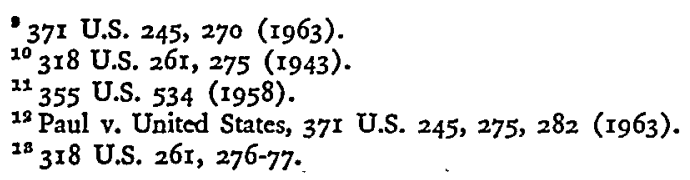


passing the Armed Services Procurement Act of 1947, has revised the federal procurement policy; presumably by re-emphasizing the "time-tested method of competitive procurement," it has now authorized administrative officials to restrict the application of local regulations which are in conflict. And secondly, the agency involved, now the Department of Defense, has issued a specific implementing regulation under the r947 statute.

The dissent elaborates on the difficulty of basing a finding of a changed federal policy on the provisions of the act or the legislative history. It is undeniable that, if the act re-emphasizes competitive procurement, it also has deeply imbedded in it substantial exceptions. In fact, Justice Douglas, apart from explaining away a subsequent amendment to the act, devotes most of his argument and places his reliance on the second aspect-the changed regulation.

It is ironic that Justice Douglas has to rely upon Department of Defense regulations to bolster and clarify a congressional policy of competitive bidding, for it is undoubtedly true that in practice breach of this policy has sometimes taken place. Perhaps "breach" is not the proper word, for the act itself provides for exceptions upon proper findings and determinations of procuring agencies, or during a national emergency declared by Congress or the President. ${ }^{14}$ Most people do not realize how long we have been living in this state of presidentially declared emergency; $;^{15}$ but anyone in day-to-day contact with government procurement, both in and out of the Department of Defense, knows of the possibility that the facts of procurement may be bent and twisted to allow for a finding and determination to avoid the competitive process.

Of course, the existence of this possibility may be justified on a principle of expediency-the argument being made that, if the time were taken to advertise or solicit proposals for every procurement susceptible to competition, we would never have closed the ballistic missile gap or would never put a man on the moon. This argument, and the statistics which arose from it, ${ }^{10}$ primarily led to the I962 amendment of the Armed Services Procurement Act by Congress. ${ }^{17}$ Thus

it 1o U.S.C. $\$ 2304$ (a) (1958).

${ }^{26}$ The Korean national emergency proclamation of President Truman was declared on Dec. 16, I950 and is still in effect despite attempts to terminate it. Cf. H.R. 5532, and ro8 CoNG. REc. 9234 (I962).

${ }_{18}$ The floor leader of H.R. 5532, Congressman Hebert, stated: "In the latest six-month reporting period, 87 per cent contract dollars were handled by negotiation... only 13 per cent of purchasing is now done by sealed competitive bidding. That is clearly not cnough." 108 CoNG. Rec. 9234 (I962). In 1955 and 1956 the percentage was 94.19 per cent of the defense procurement dollar negotiated, representing $\$ 34$ billion as against $\$ 2$ billion purchased by advertised competitive procurement. Id. at 9242 .

27 The bill as passed was Pub. Law No. $87-653,76$ Stat. 528, 10 U.S.C.A. $\$ 2304$ (1963). It is interesting to note the remarks of Congressman Vinson, Chairman of the House Armed Services Committec, on the necessity of incorporating a certificate-of-accurate-costs requirement in the bill:

"In fact, a provision for a certificate of accurate costs was put in the Armed Services Procurement Regulation after our hearings. It has been there for over two years.

"That requirement is set out in section $3-807.3$ and the form of the certificate is prescribed in section 3.807.7.

"I submit that if it is a good regulation, it will be a good law.

"The reason for putting this provision in the law is to have the requirement followed. When it is 
Justice Douglas found support for the federal policy in what the Department of Defense says (as he interprets the regulation), rather than in the practice reflected by procurement statistics.

A further irony is that Justice Douglas now requires application of the policy of competition in one of the few fields where a genuine exception to that policy (other than expediency, based on a saving of time and personnel, which is, of course, not officially recognized) might reasonably exist. Douglas recognizes this himself by saying in his decision in Paul that policy-wise it might be better if federal procurement officials honored the state price-fixing systems. Does this mean that the procuring agency has the discretion to determine, reverse, or waive federal policy? Suppose the ASPR were now changed to provide for honoring state price-fixing laws in the procurement of milk at commissaries. In the face of the decision in Paul, could the Comptroller General allow payment on such contracts?

\section{IV}

\section{Implications of Paul v. United States}

Finding congressional intent is not always easy; and to a certain extent the administrative agencies, like the courts, legislate interstitially. Between Penn Dairies and Paul, the Supreme Court, with an administrative agency assist, became willing to infer (or as Chief Justice Stone would have said, "infer lightly") the intent of Congress. The fact that the Court was willing to do this in Paul and relied so heavily on the ASPR in so doing-rather than relying on the direct restraints to which a vital federal function had been subjected by the conflicting local statutes, as in the California Commission case-gives greater significance now to the statement that regulations have the force of law. Of course, Justice Douglas said the same thing in the California Commission case; but as Justice Stewart points out in Paul, ${ }^{18}$ the Court did not really rely on that proposition then as it does now. ${ }^{19}$

Perhaps the more basic explanation of the Supreme Court's switch in policy within twenty years to allow federal procurement regulations to override state price-fixing laws without concern for their impact or lack of impact on vital federal functions lies in the increased influence of Justice Douglas and his personal philosophy on the

law, no contract will be enforceable without it. That is the point to which we have come today." I08 CoNG. REC. 9237 (1962).

${ }^{18}$ Paul v. United States, 371 U.S. 245,272 (1963):

"The opinion in the California Commission case also discussed the 1947 Armed Services Procurement Act, but nowhere suggested that the 1947 Act had changed the law upon which the decision in Penn Dairies had rested. Rather the Court distinguished the Penn Dairies case on the ground that the Pennsylvania milk marketing statute had not subjected the National Government or its officers to any direct restraints, as did the California legislation." (Footnotes omitted.)

${ }^{10}$ In a similar way in Standard Oil Co. v. Johnson, 326 U.S. $48 \mathrm{I}$ (1942), cited by Justice Douglas as authority in his dissent in Penn Dairies v. Milk Control Comm'n, 318 U.S. $26 \mathrm{r}$ (I943), the statement of the Court ". . that the establishment and control of post exchanges have been in accordance with regulations rather than specific statutory directions does not alter their status, for War Department regulations have the force of law ..." (3I6 U.S. at 484 ) is not the true holding of the Court, but is used as an ancillary argument to the decision that post exchanges are arms of the government, and share its immunities. 
Court. ${ }^{20}$ Justice Douglas, as an acknowledged expert in the field of the national economy by reason of his experience in teaching business law at the Yale Law School and as Chairman of the Securities and Exchange Commission prior to coming to the Court in $1939,{ }^{21}$ frequently writes the opinion of the Court in the field of federal procurement. The diffculty with his highly individualistic opinions lies in the subsequent application of them by those who must rely on the Supreme Court's decisions and apply them in later cases. This warrants a detailed analysis of past opinions referring to regulations having the force of law (particularly those of Justice Douglas), as well as those subsequent to the decision in Paul v. United States.

\section{V}

\section{Scope of Administrative Rule-Making}

Assuming, although Douglas never said it in so many words, that Paul means that an administrative agency my infer congressional intent from an ambiguous legislative history and bolster that intent by its implementing regulations, the question is then raised: "Do these regulations have the full force of statutory law?" And where the congressional act has been silent, but the administrative agency has interstitially legislated, based on its broad and general rule-making authority, do these regulations equally have the full force of statutory law?

The general rule on the force and effect of an administrative regulation is well set forth in another case discussing the ASPR, United States v. Barnard:22

It is the well settled rule of law that a regulation promulgated by an administrative agency charged with administration of an act has the force and effect of law if it is reasonably adapted to the administration and enforcement of the act and does not contravene some statutory provision.

However, the general rule is subject to many refinements and exceptions, three of which are set forth in the dissent in Paul. ${ }^{23}$ As American Jurisprudence, in discussing the scope of powers granted to an administrative agency, states: ${ }^{24}$

\footnotetext{
${ }^{20}$ Time, Aug. 23, 1963, p. I7, states: "As the Court now stands, the usual five-member majority (consisting of Chief Justice Earl Warren and Justices Hugo Black, William Douglas, William Brennan, Jr., and Arthur Goldberg) is characterized as 'liberal.' The four member minority (Justices Tom Clark, John Marshall Harlan, Potter Stewart, and Byron White) is called 'conservative' . . . that difference (between liberal and conservative), of course, lies in the conflict between the liberal notion that the Supreme Court should interpret the law according to the individual, often individualistic, sense of justice and injustice of its members, and the conservative proposition that Supreme Court decisions must be limited by the constitutional and legislative laws of the land."

${ }^{21}$ Cf. Casper, The Liberal Faith: Some Observations on the Legal Philosophy of Mr. Justice William O. Douglas, 22 FED. B. J. 179, I89 (1962). He states:

"The problem of the time was the creation of a strong, efficient, well-balanced national economy. Justice Douglas answered this challenge, as the professor and the administrator had answered it before.

"The legal philosophy and method applied in the decision-making of these years was basically that of legal realism. That is, an attempt was made to ascertain the social and economic facts of the day before passing judgment on what was considered to be the public interest."

${ }_{22}^{2} 255$ F.2d 583, 588-89 (10th Cir. 1958) (citing cases), cert. denied, 358 U.S. 979 (1958).

${ }^{28} 37$ I U.S. 246,270 et seg. (1963).

${ }^{24} 42$ AM. JUR. Pub. Admin. Law $\$ 53$ (1942).
} 
Since the power to make regulations is administrative in nature, legislation may not be enacted under the guise of its exercise by issuing a "regulation" which is out of harmony with, or which alters, extends or limits the statute being administered, or which is inconsistent with the expression of the lawmakers' intent in other statutes. . . . The [administrative officer] cannot initiate policy in the true sense, but must fundamentally pursue a policy predetermined by the same power from which he derives his authority.

If the regulations go beyond what Congress can authorize or beyond what it has authorized, they are void and may be disregarded. ${ }^{25}$ Regulations of a department must be issued within the powers conferred by Congress and must be addressed to and reasonably adapted to the enforcement of an act of Congress. ${ }^{26}$

Even in the field of the interpretation of Internal Revenue Regulations, where the Supreme Court gives great weight to a long established construction of tax laws by administrative action, it does not grant them the full force of statutory law.

And it is said that while no provision of the statute authorizes a specific regulation respecting this matter, the general power conferred by law to make appropriate regulations comprehends the subject. Where the act uses ambiguous terms, or is of a doubtful construction, a clarifying regulation or one indicating the method of its application to specific cases not only is permissible but is to be given great weight by the courts. And the same principle governs where the statute merely expresses a general rule and invests the Secretary of the Treasury with authority to promulgate regulations appropriate to its enforcement. ${ }^{27}$

Departmental regulations may not invade the field of legislation, but must be confined within the limits of congressional enactment. ${ }^{28}$ The distinction between regulatory and statutory law was well stated as far back as 1897 in Meads v. United States: ${ }^{29}$ "It is very true that these regulations duly promulgated by the department have the force of law, in a limited and just sense, especially when authorized or approved by Congress."

\section{VI}

\section{Is Specific Statutory Authority Necessary?}

The Court of Claims in Christian has now interpreted Paul v. United States to mean that (mandatory?) regulations have the full force of statutory law, so as to allow their incorporation in a contract otherwise silent. It has also held that no specific statutory authority or legislative history is required to obtain this effect. Judge Davis stated:" "Unless the Congress has prohibited the agency from entering some phase of the contractual process (or using some otherwise lawful method of contracting), a grant of wide and general authority to contract and procure will extend to all reasonable phases and methods." It seems doubtful that Justice Douglas

\footnotetext{
${ }^{26}$ Utah Power \& Light Co. v. United States, 243 U.S. 389 , 4xo (I9x7).

${ }^{20}$ Kirk v. United States, 270 F.2d Iro (9th Cir. I959), citing 9I C.J.S. United States $\$ 3$ I (1955).

${ }^{37}$ Koshland v. Helvering, 298 U.S. 44I, 446-47 (1936).

${ }^{98}$ Hawke v. Comm'r of Internal Revenue, rog F.2d 946 (9th Cir. 1940).

${ }^{20} 8 \mathrm{x}$ Fed. 684, 694 (6th Cir. 1897). (Emphasis added.)

${ }^{20} 320$ F.2d 345, 348. (Emphasis added.)
} 
intended such an extension of his statement that regulations have the force of law. In fact, he had already spoken on this very subject that was before the Court of Claims, in a concurring opinion in United States v. Penn Foundry \& Mfg. Co., Inc. ${ }^{31}$ In this case involving termination by the Navy Department of a Letter of Intent, the Supreme Court refused to allow the contractor to recover for anticipated profits due to failure of proof, and in his concurring opinion Justice Douglas, joined by three other Justices, stated that the contractor could have recovered had it presented sufficient evidence to overcome the Navy's general policy of incorporating termination clauses in the resulting formal contracts prohibiting such recovery. "Respondent, however, has not carried the burden of showing that it would have been saved from the application of that policy."32 But in a footnote the statutory authority was pointed out: ${ }^{33}$

At that time Title II of the First War Powers Act ... was in effect empowering the President to authorize any department or agency exercising functions in connection with the prosecution of the war effort under regulations prescribed by him "to enter into contracts and into amendments or modifications of contracts heretofore or hereafter made ... without regard to the provisions of law relating to the making, performance, amendment, or modification of contracts whenever he deems such action would facilitate the prosecution of the war...."

In all the cases cited by Judge Davis for support, ${ }^{34}$ however (with the exception of Kern-Limerick, Inc. v. Scurlock ${ }^{35}$ ), the Court relied upon, or at least referred to, congressional intent as contained in more or less specific statutory language dealing with the subject at issue. Judge Davis admits that termination for convenience authority is no longer covered by "... the generous umbrella of Title II of the First

3133 U.S. 198 (1949).

${ }^{32}$ Id. at 216.

${ }^{33}$ Id. at 215 n.4 (citing First War Powers Act, $\$ 201$, 55 Stat. 839, 50 U.S.C. $\$ 6 \mathrm{II}$ (1958)).

${ }^{84}$ Kern-Limerick, Inc. v. Scurlock, 347 U.S. r10, 114 ff. (r954); Public Utilitics Comm'n of California v. United States, 355 U.S. 534 (1958); Paul v. United States, 371 U.S. 245 (1963); United States v. Penn Foundry \& Mfg. Co., Inc., 337 U.S. I98 (I949) (opinion of Mr. Justice Douglas).

${ }^{85}$ There is always a tax case which is the exception that proves the rule. In Kern-Limerick, supra note 34, at II6, the Court held: "We find nothing in the Procurement Act that bars a contract for purchase for the United States of supplies or services by private persons."

"The Government asserts that $\S{ }_{4}(\mathrm{a})$ and ${ }_{4}(\mathrm{~b})$ authorize this contract. Under them, negotiated contracts such as this 'may be of any type which ... - will promote the best interests of the Government:' Under such a provision, it seems that the determination to use purchasing agents is permissible. Where there is no prohibition of a particular type of contract and no direction to use a particular type, the contracting officers are free to follow business practices." Id. at II6.

It is interesting to note that Justice Black, along with Chief Justice Warren, and Justice Douglas, who. are now normally aligned with the majority bloc of the Court, dissented on this very point:

"The Court holds that Government purchasing agents can delegate to their subordinates authority to delegate to private persons power to buy goods for the Government and pledge its credit to pay for them. Alabama v. King \& Boozer, 314 U.S. I, I3 (I94I), rejected a similar contention. The Court points to no statute which either expressly or by fair implication grants any such broad delegation authority to Government agents." - Id. at 123.

In view of this dissent and the present constitution of the Supreme Court, the authority of this case is dubious. Although the "agency" theory has come under much criticism in Congress, there has been no legislation enacted to date. Cf. DA Pamphiet 27-153, Procurement Law 305 (I96I). 
War Powers Act of December 18, I941 ...." This therefore forces him to rely on broad and general powers, and to take the previously quoted sentence of Priebe entirely out of context.

\section{VII}

\section{The Practical Problem of Conflicting Regulations}

Nevertheless, it might be argued that the Court of Claims in Christian is allowing the Department of Defense to do exactly what the Supreme Court allowed it to do in Paul-infer the intent of Congress, or, in the absence thereof, interstitially to legislate the policy. But to then go on and incorporate these regulations "by operation of law," just as though they were based on a clearly stated statute, leads only to creating more problems than it settles.

The problems are inherent in the existence of the multitudinous federal procurement agencies. The NASA, for example, is brought under the purview of the Armed Services Procurement Act by section 30I(b) of Public Law 85-568; but the agency interprets this statute to include only the act and not the regulations issued pursuant thereto, since its basic statute ${ }^{36}$ has the same broad and general authority that exists under the Armed Services Procurement Act. How this works out is revealed in the very area of Christian. The NASA interpretation in the area of conflict between the mandatory clauses of the ASPR and specific contractual provisions on termination is that the clauses used in the contract will control the regulation. ${ }^{37}$ Now, if the ASPR is the supreme law of the land and its application is made mandatory, it would appear that this NASA regulation is in contravention thereof and must fall. One way out of this dilemma is to say that each agency is supreme in its own contractual relations and that by administrative agreement they will follow common policy to the extent each sees fit. But there is a third horn to this dilemma, because Congress has specifically directed by amendment ${ }^{38}$ to the Federal Property and Administrative Services Act of $1949^{39}$ that each federal agency shall utilize such uniform standardized forms and procedures as are prescribed by the Administrator of General Services, except as the Administrator shall otherwise provide. The General Services Administrator has seen fit by Federal Procurement Regulation I-I.004 to exclude the Department of Defense from the mandatory provisions of the Federal Procurement Regulation "except for standard government forms and clauses, Federal Specifications and Standards, and except as directed by the President, Congress, or other authority ...." This, too, was accomplished by administrative agreement. The intended result is described in a report by General Services Administration, prepared at the request of the Senate Committee on Government Operations: $:^{40}$

\footnotetext{
${ }^{80}$ National Aeronautics and Space Act of 1958, Pub. L. No. 85-568, 72 Stat. 426, as amended, 42 U.S.C. $\$ 2451$ (1958).

${ }^{37}$ National Aeronautics and Space Administration (NASA) Procurement Regulation 8.000(b).

${ }^{88} 66$ Stat. 593 (1952), 40 U.S.C.A. $\$ 487$ (1963).

${ }^{30} 63$ Stat. 393 (1949), as amended, 40 U.S.C.A. $\$ \$ 25 \mathrm{I}-60(1963)$.

${ }^{40}$ General Services Administration, Report, S. REP. No. -, 85th Cong., 2d Sess. 47 (I959).
} 
The authority to standardize Government purchase and contract forms, procedures and specifications has been in effect and in use for many years and is demanded by industry to make its relations with the Government easier. It is confusing and costly, for example, to have a contract with terms, forms, and conditions for a supply item with one agency differing in meaning and effect from one for the same kind of item with another agency. ...

The Comptroller General recently ruled on a conflict in regard to a standard clause for consideration of late bids. ${ }^{41}$ Not only did a conflict exist between the Federal Procurement Regulation and the ASPR, but also within various sections of the Armed Services Procurement Regulation itself. The Comptroller General held that the Federal Procurement Regulation clause ". . . is a standard clause which by law and regulations is prescribed for use by all federal agencies including the Department of Defense . . . although use of that clause was not compulsory until January 2, I963." Effective February 18, 1963, the Department of Defense amended its policy regulations to prevent a conflict with the ASPR "late bids"42 clause, but the Armed Services Procurement Regulation still clearly is in conflict with the FPR policy in this field.

\section{VIII}

\section{Legality As Distinguished From Policy-Douglas's Views}

In the decision denying a rehearing in Christian, Judge Davis said that the Court was not concerned with whether the policy of incorporation by regulation is the best policy in this matter; its only concern was with the legality of this incorporation. He cited Justice Douglas in Paul to establish that administrative regulations have the force of law, and Justice Douglas in Penn Foundries for the view that policy provisions need not be spelled out in a contract. He also cited Justice Douglas in Priebe concerning the extent of the broad powers granted in the general power to contract.

Mr. Justice Douglas himself stated in Paul that the Court was not concerned with the appropriateness of a policy but with what the policy was. Although, in effect, inferring the intent of Congress from the implementing administrative regulations, he did not omit the step of referring to the congressional intent as revealed by legislative history. Neither did he in Penn Foundries omit that step; again he referred to the legislative background. But the place where he has most clearly indicated that congressional approval cannot be wholly inferred, just because it has granted broad general powers and has not disapproved the policy promulgated, is in Priebe. There, as has been previously mentioned, Judge Davis seems to have quoted him wholly out of context. The case itself is, of course, distinguishable on other grounds - that the clause involved was deemed violative of general contract law. But then changing or adding to specific contract terms so as to eliminate proven anticipated

${ }^{21}$ See B-r 50514, March 22, 1963, 42 Comp. Gen. -

${ }^{2}$ Armed Services Procurement Regulation (ASPR) 2-303.2, 32 C.F.R. $\$ 2.303-2$ (1963). 
profits upon breach of contract produces a result not obtainable under general contract law" ${ }^{43}$ and therefore before sanctioning such a change "congressional purpose should be plain." 44

\section{IX}

\section{A Reasonable and Legal Policy}

Would it not be more reasonable to say that, where Congress has not indicated a clear intent, each agency is authorized to regulate its own activities and its regulations will be binding on its own members; however, they will be binding as to third parties only to the extent that those parties agree to them by contract? This is the well established construction of section twenty-two of Title Five (general authority to the head of each department to ". . . prescribe regulations, not inconsistent with law, for the government of his department ...").45 Of course, in this case the statutory language lends itself to this construction.

Once we agree on the principle that for a regulation to have the full force of statutory law it must be promulgated pursuant to a clearly stated congressional policy, then we can agree with the further argument advanced by Judge Davis on the rehearing in Christian that subordinates cannot be allowed to sap regulations issued by superiors. But to apply that policy to all the varying regulations, or even to just the standard or mandatory regulations, issued by the multitudinous procurement agencies would lead only to the confusion already mentioned. It might also lead to contractors' demanding of every contracting officer that he show specific authority for entering into each and every contract. If the rule in Christian were applied widely, the present contracting officer's warrant to enter into contracts would not be of much value.

In these days of growing detailed supervision of contracts and subcontracts by government procurement officials, the contractor more and more seeks special language in his contract varying in one degree or another from standard terminology or "boiler plate." As Judge Davis indicated, if these are recognized deviations, then a procedure exists for obtaining approval from superior authority. But what if in good faith the contracting officer, exercising what was theretofore thought to be his discretion, determines that the changed language is not a true deviation and does not forward it to headquarters, hoping thereby to avoid that bugaboo of all procurement officials-delay?

It would indeed be unfortunate if, in these days of demand for streamlined

${ }^{43}$ As established by United States v. Behan, I Io U.S. 338 ( $\left(88_{4}\right)$.

"De Laval Steam Turbine Co. v. United States, 284 U.S. 6I (I93I), emphasizes the reliance upon statutory authority (Act of June $15,19 \mathrm{I}$, par. I, 40 Stat. 182) to the President based upon wartime conditions. Cf. Russell Motor Car Co. v. United States, 26r.U.S. 514 (I923).

${ }^{45}$ Cf. I7 Ops. Atry. Gen. 524 (I883), cited in notes to 5 U.S.C.A. $\$ 22$ ( 1963 ):

"No authority is created by this section which enables the heads of departments to make rules for the conduct of persons not connected with the departments, but such regulations, when made, are exclusively for the government of the department, and the conduct of its officers, and the preservation of the papers and property belonging to the department." 
procurement methods to allow us to reach national prestige objectives on schedule, the contracting officer were forced to wait for headquarters' approval of every change in standard clauses for fear that it later may be held to be a deviation from an administrative regulation which "has the force of law." Neither Justice Douglas nor the Supreme Court in Paul v. United States ever intended that result.

\section{EPILOGUE}

Now, nine months after the writing of the original article, and more than a year after the decision in Paul v. United States, was handed down, can we say with assurance that federal procurement regulations "have, of course, the force of [statutory] law"? In order to demonstrate that the unqualified use of that proposition on occasion even "sticks in the craw" of the Court of Claims, it is illuminating to examine two decisions handed down by the court on December 13, 1963-the Goldwasser case, ${ }^{46}$ and the Reiner case. ${ }^{47}$

These cases both involved the applicability of the termination for convenience clause, which was contained in the contracts. I submit that whether the clause was in the contract or not is immaterial if procurement regulations (which provided the same thing) have the full force of law. If the court really accepts that proposition, then there should be no argument about applicability. The Supreme Court in College Point Boat Co. v. United States, ${ }^{48}$ decided that when Congress had passed a statute authorizing termination for the convenience of the government there was an unqualified right in the government to cancel or terminate at any time. In other words, if the authority to terminate for the convenience of the government is contained in a regulation which has the force of statutory law, then the parties are held to have contemplated it, whether in the contract or not. But the majority of the court in Goldwasser fell back on its 196r decision in Klein v. United States, ${ }^{40}$ and held that where no previous attempt had been made to terminate for convenience, the government could not fall back upon a right which existed but was never asserted until it was found to be in breach of contract. They said "it would be anomalous indeed if it could," which must mean it offends their sense of justice in this case.

But on the same day, it handed down the Reiner decision, in which the majority of the court applied the termination for convenience clause after the fact although they disagreed on the reasons therefor. The rationale of the court shows the confusion which results from equating regulations (or clauses) which do not have statutory authority with those which do. We can all agree that the government is different from a private contractor, and that there are circumstances when the best interests of the government give it the right to terminate for convenience. But it does not seem equitable to allow an administrative agency to arrogate to

${ }^{48}$ Goldwasser v. United States, 325 F.2d 722 (Ct. Cl. 1963).

${ }^{47}$ John Reiner \& Co. v. United States, 325 F.2d 438 (Ct. Cl. 1963).

${ }^{18} 267$ U.S. I 2 (I925).

${ }^{10}{ }_{285}$ F.2d 778 (Ct. Cl. I96r). 
itself the right to avoid a wrongful breach of contract, whether committed intentionally or not, and whether by means of contract clause or regulation, in violation of general contract law. The determination of the proper circumstances should be made by the Congress, or else the authority should be by clear legislative grant.

If one can reconcile and harmonize these decisions he may know the true answer to the question which I originally asked. For he will be a procurement expert. And we all know an expert is a man who makes mistakes with confidence. I, like most people who have helped to write regulations, have no more confidence in the force of procurement regulations now than I did before. In that respect I am like my old chief in the Air Force Space Systems Division. Once, upon my return from discussing with headquarters a contract negotiation, I said that I hesitated to tell him what happened for fear that he would lose confidence in us. His reply was: "That's all right. You can go ahead and tell me. I never had any confidence in you in the first place."

The truth is that the continued use of Justice Douglas' proposition in the way it has been applied since G. L. Christian \& Associates serves only to thicken what some of our distinguished jurists have termed the "administrative fog." The administrative agencies continue to arrogate authority to themselves, and to issue regulations to implement that authority. Although the Department of Defense has attempted to clear the fog by abolishing separate procurement regulations for its separate services, it is to be noted that they have only succeeded in clearing a small hole in the fog. Concurrently with the Department of Defense action, the Commerce Clearing House felt obliged to create a new volume to accommodate the multitude of procurement regulations newly issued by the other governmental agencies involved in procurement. And the regulations do not all say the same thing-sometimes by design, and sometimes purely by accident. If they all "have, of course, the force of law," the government contractor has a terrible burden to bear. He is presumed not only to know all the statutory law, but also all the diverse regulations. He must not only make sure that the contract says what he wants it to, but that the contracting officer did not make any mistake.

$\mathrm{U}_{\mathrm{p}}$ to the time of the G. L. Christian \& Associates decision, the contractors could at the negotiation table refuse to accept certain clauses in their contracts or, more usually, they could write in schedule provisions which could be interpreted to cover their views in those areas while leaving the general provisions unchanged. Then they could argue that if there was any conflict the special provisions overrode the general.

Now in these days when the long arm of the government is reaching further and further into the areas in which contractor management feels it has some prerogatives, such as sub-contract management and the extent of allowable technical direction, there seems to be no way out other than by the contractor insisting on headquarters approval of any significant schedule provisions as well as the "boiler plate." 
For both legal and policy reasons the Court of Claims should limit the effect of the G. L. Christian \& Associates decision strictly to its special facts. If not, then I support in principle the efforts of the attorney for Christian \& Associates in what he has described as his third bite at the Supreme Court by way of certiorari. Maybe then Justice Douglas will explain that he did not mean that federal procurement regulations "have, of course, the force of law," in an unqualified sense. 